УДК 159.942(076)

DOI 22185186.2019.1.05

Ірина Матійків

\title{
ФОРМУВАННЯ ГОТОВНОСТІ ПСИХОЛОГА ДО МАЙБУТНЬОЇ ПРОФЕСІЙНОЇ ДІЯЛЬНОСТІ
}

Актуальним завданням сучасної освіти є фахова підготовка психолога, професійна майстерність якого відповідала б європейським стандартам і потребам суспільства. У процесі професійного становлення під час навчання у закладі вищої освіти (3ВО) майбутній психолог має оволодіти системою різних умінь для здійснення діагностичної, корекційної, розвивальної, експертної, консультативної, управлінської, а також викладацької та науково-дослідної (для освітньо-кваліфікаційного рівня «Магістр») професійної діяльності. Окрім того, готовність психолога до професійної діяльності передбачає наявність не лише конкретних професійних знань, умінь і навичок, а й особистісних якостей, які забезпечують ефективність іiі виконання. Адже основним інструментом діяльності психолога $є$ його особистість. Саме через свою особистість психолог чинить цілющий вплив на клієнтів.

Згідно з нашим припущенням, розвиток професійної майстерності під час навчання передбачає цілеспрямоване формування готовності психолога до майбутньої діяльності, найважливішими складовими якої є: особистісна готовність (сформованість ціннісно-мотиваційної сфери, позитивне ставлення до майбутньої діяльності, самостійність, відповідальність, адекватна самооцінка, асертивність поведінки, об'єктивність, конгруентність, комунікативна толерантність, емпатійні здібності, емоційна стійкість, урівноваженість, цілеспрямованість тощо) і функціональна (володіння психологічним інструментарієм і технологіями, техніками, методами, необхідними для виконання різних видів професійної діяльності психолога; сформованість загальнопрофесійних і спеціальних умінь, які відповідають психологічній структуpi діяльності). На наш погляд, від фахівців потрібна не просто готовність до успішної діяльності, а готовність до діяльності в сучасних умовах динамічних змін у світі технологій і в суспільному житті.

3 огляду на сказане, підвищення якості професійної підготовки майбутніх психологів потребує розвитку їх особистісної та функціональної готовності до майбутньої діяльності.

(C) Ірина Матійків, 2019 
Встановлено декілька головних напрямів у вирішенні питання про характерологічні особливості готовності до професійної діяльності: розробка поняття і структури готовності (О. Абдуліна, Л. Долинська, Є. Клімов, В. Крутецький, Н. Кузьміна, М. Левченко, А. Маркова, В. Сластьонін, Т. Яценко та ін.); пошуки шляхів оптимізації формування готовності до різних аспектів педагогічної діяльності (Л. Долинська, Р. Немов, Н. Чепелєва та ін.); аналіз структурних компонентів і показників готовності до педагогічної діяльності (Г. Балл, А. Деркач, В. Семиченко, В. Сластьонін та ін.); пошуки рівнів сформованості психологічної готовності (М. Боришевський, А. Ганюшкін, М. Дьяченко, Л. Кандибович, Л. Кондрашова та ін.).

Аналіз наукових джерел дозволяє зробити висновок, що, незважаючи на значну кількість теоретичних досліджень з означеної проблеми, окремої уваги потребує розробка навчально-практичних інтерактивних курсів, соціально-психологічних тренінгів (СПТ), які б сприяли формуванню професійної готовності майбутніх психологів у період оволодіння професією. СПТ надають можливості забезпечити високу пізнавальну активність студентів; розвивати рефлексивне мислення, комунікативні навички, а також дозволяє за порівняно короткий час вирішити завдання інтенсивного формування і розвитку професійно значущих навичок і вмінь.

Цій проблемі й присвячена стаття, мета якої полягає у висвітленні структури навчально-практичного курсу «Основи професійної майстерності психолога», розробленого на основі тренінгових технологій, а також ключових принципів, ціннісних настанов, формування яких сприяє вдосконаленню особистості майбутнього психолога. Розроблений нами навчально-практичний курс має на меті вдосконалення професійно важливих умінь і особистісних якостей, необхідних для успішного здійснення майбутньої професійної діяльності.

У психології поняття «готовність» розглядається з різних позицій: як наявність здібностей (Б. Ананьєв, С. Рубінштейн), як ознака настанови (Д. Узнадзе), як психічний (В. М'ясищев) чи психологічний стан (П. Ганушкін, А. Пуні), як психологічний процес (Е. Еріксон). За психолого-педагогічним словником, психологічна готовність як суттєвий компонент професійної готовності є передумовою ефективності діяльності після завершення навчання. Вона допомагає молодому фахівцю успішно виконувати свої обов'язки, використовувати знання, досвід, зберігати самоконтроль і гнучко реагувати на непередбачувані перешкоди, швидко адаптуватися до умов праці. На психологічну готовність впливають індивідуально-психологічні якості особистості, 
стійкі настанови на виконання конкретних дій, мотиви, психічні стани тощо [11, с. 638].

Готовність, на думку М. Д’яченко та Л. Кандибович, це актуалізація можливостей особистості у конкретний момент для здійснення успішної дії, внутрішнє налаштування на певну поведінку при виконанні навчальних і трудових завдань, настанова на активні дії [3, с. 27].

Важливим для дослідження є виокремлення науковцями загальної та ситуаційної готовності [2]. Загальна готовність фахівця визначається сформованими професійно важливими якостями, настановами, знаннями, навичками, вміннями, мотивами діяльності тощо. Проте це ще не означає, що він спроможний здійснювати результативно необхідні дії, тобто насправді «готовий діяти». У психологічних джерелах «готовність до дії» трактується як «стан мобілізації всіх психофізіологічних систем людини, що забезпечує ефективне виконання конкретних дій» [10, с. 89]; стан, у якому людина налаштована на дію і можливість отримати користь із досвіду [8]. Ситуаційна готовність до діяльності полягає у вмінні впевнено ухвалювати емоційно розумні рішення, внутрішньо налаштовуватися, мобілізовувати психологічний потенціал для здійснення запланованих дій у конкретний момент адекватно до професійної ситуації; вона передбачає наявність вольових якостей. Таким чином, загальна готовність $є$ основою ситуаційної готовності до дій або виконання поточних завдань діяльності.

Враховуючи вищевикладені погляди учених, тлумачимо поняття «психологічна готовність психолога до діяльності» як сформованість у нього взаємопов'язаних і взаємозумовлених досвіду, особистісних якостей, знань із галузі психології, умінь і навичок, ціннісних настанов, які знаходять вияв в ухваленні емоційно розумних рішень, здійсненні доцільних дій адекватно до професійної ситуації та забезпечують успішність процесу виконання різних видів робіт.

У якості засобу цілеспрямованого формування професійної готовності майбутніх психологів до діяльності розроблено навчально-практичний інтерактивний курс «Основи професійної майстерності психолога» [5]. Його програма підготовлена відповідно до навчального плану і складається з двох модулів: «Особистісне зростання психолога» та «Розвиток загальнопрофесійних умінь». Кожний модуль охоплює окремі теми, які розкривають зміст курсу. Перший модуль присвячений формуванню індивідуально-психологічних якостей, переконань, цінностей, настанов, необхідних майбутньому фахівцеві для якісного виконання професійної діяльності. Другий модуль передбачає засвоєння знань із галузі психології, оволодіння сучасним психо- 
логічним інструментарієм, прийомами i техніками психологічної практики.

Тематичний план змісту навчально-практичного курсу «Основи професійної майстерності психолога» складається 3 двох модулів і охоплює такі теми:

Модуль I. «Особистісне зростання психолога». Особистість психолога як інструмент його професійної діяльності. Цінності у професійній діяльності психолога. Відповідальність як складова професійної майстерності психолога. Усвідомленість життя. Сприйняття і визнання реальності. Позитивна налаштованість і «магнетизм» психолога. Асертивність і конгруентність психолога. Психологічні кордони особистості.

Модуль II. «Розвиток загальнопрофесійних умінь». Мова як засіб впливу. Невербальна комунікація. Мистецтво емоційної саморегуляції психолога. Управління емоціями як професійно важливе уміння психолога. Комунікативна компетентність психолога. Кроки назустріч. Позитивна взаємодія у складних комунікативних ситуаціях.

Із психологічної теорії навчання відомо, що інформація тільки тоді стає внутрішнім надбанням особистості, коли вона випробувана, відпрацьована на реальних об'єктах, у реальних ситуаціях, хоч і навчальних [13]. Методичною особливістю курсу «Основи професійної майстерності психолога» $є$ проблемність викладання, яка досягається через залучення студентів до обговорення різних питань, надання їм можливості висловлювати власну думку, робити висновки. Результативність засвоєння навчального матеріалу поліпшується завдяки застосуванню активних та інтерактивних методів навчання (дискусії, мозкові штурми, рольові ігри, евристичні бесіди, аналіз ситуацій, тренінгові вправи, тестування, тематичні вправи, ділові ігри, відеоаналіз та ін.) [4; 6; 7; 12, с. 83-96].

Також програмою передбачено самостійну роботу студентів, яка полягає у: складанні відповідей на запитання («Мотивуючий контроль»); виконанні домашніх завдань, які вміщують основний матеріал теми; заповненні щоденника; підготовці рефератів, повідомлень, доповідей на запропоновані теми та ін. Самостійна робота сприяє тому, щоб отриманий на заняттях досвід перетворився на практичні професійно і життєво важливі навички й уміння.

В основу навчально-практичного курсу покладено ключові принципи і переконання, ціннісні настанови, формування яких сприяє вдосконаленню особистості майбутнього психолога. До них віднесено такі:

1. Фокус уваги на цінностях. У цінностях відображається розуміння людиною дійсності, переконання щодо довкілля і самої себе, вони ста- 
новлять глибинний рівень, який структурує досвід людини як особистості, визначає іiі культуру, якість життя та професійної діяльності. Саме цінності, переконання, внутрішні настанови слугують орієнтирами, визначаючи напрям руху в життєвому просторі, допомагають пам'ятати про пріоритети, зосереджуватися на найважливішому, досягати бажаного. Вони визначають характер вчинків і діяльності особистості, саме від них залежить те, який зміст надаємо подіям і як емоційно реагуємо на них, як чинимо у різних ситуаціях, ухвалюємо те чи інше рішення [9].

До цінностей професії психолога науковці відносять: спрямованість на допомогу клієнту; віра в людей, позитивна установка щодо них (L. Brammer, M. Еріксон, Р. Мей), віра у здатність клієнта долати життєві труднощі (В. Панок, Н. Чепелєва), до позитивних змін і розвитку; уміння зберігати таємницю; готовність до співпраці та спрямованість на позитивний результат діяльності та ін.

Лише усвідомлюючи та шануючи власні цінності, розуміємо і визнаємо унікальність внутрішнього світу і цінності інших людей.

2. Відповідальність. В основі діяльності психолога - високий рівень особистісної відповідальності, інтернальність (внутрішній локус контролю), усвідомлення меж власної компетентності, уміння розподіляти відповідальність із клієнтом, самостійність в ухваленні рішень.

3. Позитивне налаштування щодо себе, інших людей, Світу. Основою позитивного налаштування є життєва позиція особистості «Я - в порядку, інші - в порядку» (Т. Харріс), уміння зберігати / підтримувати внутрішній стан рівноваги й емоційного благополуччя. Психолог створює навколо себе сприятливий для взаємодії та взаєморозуміння простір саме тоді, коли сам перебуває у стані внутрішнього психологічного благополуччя. Саме по собі ставлення до клієнтів із повагою, як до цілісної і дієздатної особистості, з великою ймовірністю викликає позитивний відгук із їхнього боку, забезпечує ефективність психологічного консультування.

4. Усвідомленість життя, процесу взаємодії, визнання реальності. Принцип усвідомленості полягає в присутності «тут і тепер», спостережливості до того, що відбувається всередині себе і навколо. Застосування принципу реальності у житті означає просто спостерігати і визнавати реальність, життєві обставини, відмінності між людьми замість оцінювання і засудження; бути зосередженими на процесі взаємодії й уважними до співрозмовника, його емоційного стану і потреб; уважно слухати, конкретно висловлювати свої думки, чинити осмислені дії. Адже кожна людина є особливою і своєрідною, зі своїми поглядами на життя, цінностями і переконаннями, культурою, вихованням, характером, здібностя- 
ми, життєвим досвідом тощо. Цінним подарунком для співрозмовника $є$ створення простору, в якому безпечно «бути собою».

5. Асертивність, відчуття міри і такту забезпечують найбільш сприятливу атмосферу в комунікативних ситуаціях. Емоційні крайнощі, як бурхливі, некеровані переживання, так і байдужість, відсутність емоцій, створюють дискомфорт у спілкуванні. «Золотою серединою» між агресивною і пасивною є асертивна поведінка. Асертивна особистість завжди відчуває, коли ії поведінка буде недоречною, і може утримати себе від некерованого сплеску емоцій, бере на себе відповідальність за власний емоційний стан, вміє відстоювати свою думку, регулювати межу втручання у власний внутрішній світ, захищати себе від впливу некоректних думок і бажань, приниження, маніпулювання з боку інших людей. Розглядаємо асертивність і вміння налагоджувати здорові психологічні кордони як професійно важливі для професії психолога.

6. Управління власними емоціями та думками. На жаль, природа не забезпечила нас особливою кнопкою, яка дозволяла б відключати емоції у тих ситуаціях, коли не хочемо їх переживати. Водночас існує чимало способів, за допомогою яких можемо давати вихід негативним емоціям, зберігати душевну рівновагу, підтримувати позитивне налаштування тощо. Щоб працювати психологом, потрібно навчитися управляти собою, зберігати внутрішню рівновагу і позитивне налаштування до співрозмовника незалежно від того, що відбувається усередині чи зовні; бути витриманим, толерантним до невизначеності; виважено сприймати спонтанність і непередбачуваність життя тощо.

7. Відкритість змінам. «Зміни не тільки можливі, а й неминучі. Люди змінюються» (М. Еріксон). Внутрішній світ особистості та зовнішній світ постійно змінюються. Початок нових справ, досягнення бажаного або вирішення життєвих завдань пов'язано 3 внесенням змін, навіть із ризиком. Будучи психологічно готовими до несподіваних поворотів подій, тим самим налаштовуємося бути гнучкими у реагуванні на зовнішні зміни [1, 139-155]. Довіра до процесу життя, його проживання без очікування неприємностей; визнання подій, які відбуваються, внутрішні установки на кшталт «Усе, що відбувається, на краще», «Усе, що відбувається, має сенс і є закономірним», «Усе відбувається своєчасно і тоді, коли потрібно»; уміння отримувати досвід із ситуацій, які трапляються, «вчитися на помилках» - все це дає відчуття безпеки, підтримки, впевненості, послаблює неприємні переживання. Завдяки змінам відбувається набуття досвіду, розвиток, удосконалення особистості психолога. 
8. «Магнетизм» особистості. Специфіка діяльності психолога полягає в тому, що саме його особистісні якості, енергетика, харизма, імідж, стиль роботи визначають вплив на клієнта або аудиторію, а також результат діяльності. Виокремлюємо такі характеристики «магнетичної» особистості: привітність, неординарність, оптимізм, здатність до зарядження енергією інших людей, надихання їх на певні дії та вчинки, упевнена манера поведінки, здатність володіти собою і ситуацією, новизна ідей, незалежність i самостійність у рішеннях і вчинках, позитивне сприйняття, захоплення 3 боку інших людей, емоційна привабливість для людей, добрі риторичні здібності, вміння висловлюватися точно і лаконічно та ін.

9. Позитивна взаємодія. Уміння позитивно взаємодіяти - це мистецтво слухати і чути, бачити і відчувати, розуміти співрозмовника i доносити до нього свої думки, конструктивно вирішувати комунікативні завдання, досягати позитивних результатів у сумісній діяльності. Позитивна взаємодія передбачає самоповагу, шанобливе і неупереджене ставлення до співрозмовника. Це позиція достойної людини, яка поважає себе і визнає гідність інших, прихильно ставиться до себе і до довкілля, цінує добрі стосунки, налагоджує їх на партнерських засадах і позитивних емоціях; вважає інших здібними й упевнена, що вони володіють всіма можливостями досягати добрих результатів.

10. Вдячність. Почуття подяки має велику силу творити і змінювати життя на краще, поліпшувати стосунки. Вміння знаходити позитивні моменти навіть у складних ситуаціях; радіти простим речам, цінувати те, що $\epsilon$, і бути вдячними долі навіть за найменші подарунки i досягнення є основою благополуччя. По-справжньому щасливі та самодостатні люди є вдячними. Це так просто і так складно водночас.

Розвиток психологічної готовності майбутніх психологів до професійної діяльності та включення навчально-практичного інтерактивного курсу в процес професійної підготовки має важливе значення для підвищення їі якості. Змістове наповнення занять може видозмінюватися залежно від особистості й рівня професійної підготовки викладача, складу групи, від кількості академічних годин. Наукова інформація і практичні розробки, запропоновані авторами програми, можуть комбінуватися залежно від мети, завдань і умов. Творче використання матеріалів психологічного практикуму прискорить процес досягнення студентами особистісної зрілості та як суб'єктів діяльності їхньої конкурентоздатності та мобільності при виконанні функціональних обов'язків. 


\section{Jimepamypa:}

1. Аткинсон М., Чойс Р. Т. Мастерство жизни: внутренняя, динамика развития : пер. с англ. М. : Альпина Паблишер, 2012. 214 с.

2. Душков Б. А., Смирнов Б. А., Королев А. В. Психология труда, профессиональной, информационной и организационной деятельности : словарь / ред. Б. А. Душкова; прил. Т. А. Гришиной. 3-е изд. М. : Академический Проект : Фонд «Мир», 2005. 848 с.

3. Дьяченко М. И., Кандыбович Л. А. Психологические проблемы готовности к деятельности. Минск : Изд-во БГУ, 1975. 173 с.

4. Матійків I. М. Тренінг емоційної компетентності : навч.-метод. посібник. К. : Педагогічна думка, 2012. 112 с.

5. Матійків I. М., Ковальчук 3. Я. Основи професійної майстерності психолога : навч.-метод. посібник. Львів : Львівський державний університет внутрішніх справ, 2016. 340 с.

6. Матійків I. М., Якимів А. І., Черняк Т. Г. Основи тренерської майстерності : навч.-метод. посіб. Львів : Компанія «Манускрипт», 2012. 392 с.

7. Мілютіна К. Л. Теорія та практика психологічного тренінгу : навч. посіб. К. : МАУП, 2004. $192 \mathrm{c}$.

8. Оксфордский толковый словарь по психологии / ред. А. Ребера ; пер. с англ. Чеботарева Е. Ю. М. : Вече АСТ, 2003. Т. 1. 592 с.

9. Педагогічні засади розвитку духовної культури педагогічного персоналу : посібник / за ред. Е. О. Помиткіна, 3. Л. Становських. Кіровоград : ІмексЛТД, 2013. $174 \mathrm{c.}$

10. Психологічна енциклопедія / укл. О. М. Степанов. К. : Академвидав, 2006. 424 с.

11.Психолого-педагогический словарь / сост. Е. С. Рапацевич. Минск : Современное слово, 2006. 928 с.

12.Яценко Т. С. Психологічні основи групової психокорекції : навч. посіб. К. : Либідь, 1996. 264 с.

13.Henson K. T. Methods and strategies for teaching in secondary and middle schools. N. Y . : Longman, 1988. X. 405 p.

\section{References (transliterated and translated):}

1. Atkinson M., Choice R. T. Masterstvo jizni: vnutrennyaya dinamika razvitiya : per. s angl. (Mastery of Life : Internal dynamics of development : trans. From English). Moscow : Alpina Pablisher, 2012. 214 p. (in Russian).

2. Dushkov B. A., Smirnov B. A., Korolev A. V. Psihologiya truda, professionalnoy, informatsionnoy i organizatsionnoy deyatelnosti : slovar (Psychology of labor, professional, informational and organizational activities : Vocabulary) / Ed. B. A. Dushkova; app. T. A. Grishina. 3 ed. Moscow : Akademicheskiy Proekt : Fond «Mir», 2005. 848 p. (in Russian).

3. Diachenko M. I., Kandyibovich L. A. Psihologicheskie problemyi gotovnosti k deyatelnosti (Psychological problems of readiness for activity). Minsk : Izd-vo BGU, 1975. 173 p. (in Russian).

4. Matiikiv I. M. Treninh emotsiinoi kompetentnosti : navch.-metod. posibnyk (Training of emotional competence : Manual). Kyiv : Pedahohichna dumka, 2012.112 p. (in Ukrainian). 
5. Matiikiv I. M., Kovalchuk Z. Ya. Osnovy profesiinoi maisternosti psykholoha : navch.-metod. posibnyk (Basics of psychologist's professional skills : Manual). Lviv : Lvivskyi derzhavnyi universytet vnutrishnikh sprav, 2016.340 p. (in Ukrainian).

6. Matiikiv I. M., Yakymiv A. I., Cherniak T. H. Osnovy trenerskoi maisternosti : navch.-metod. posib (Basics of coaching skills: Manual). Lviv : Kompaniia «Manuskrypt», 2012. 392 p. (in Ukrainian).

7. Miliutina K. L. Teoriia ta praktyka psykholohichnoho treninhu : navch. posib. (Theory and practice of psychological training: Tutorial). Kyiv : MAUP, 2004. 192 p. (in Ukrainian).

8. Oksfordskiy tolkovyiy slovar po psihologii (Oxford Dictionary of Psychology)/ Ed. A. Rebera ; transl. from English Chebotarev E. Yu. Moscow : Veche AST, 2003. Vol. 1. 592 p. (in Russian).

9. Pedahohichni zasady rozvytku dukhovnoi kultury pedahohichnoho personalu : posibnyk (Pedagogical bases of development of spiritual culture of pedagogical staff : Manual) / Ed. by E. O. Pomytkin, Z. L. Stanovskykh. Kirovohrad : ImeksLTD, 2013. 174 p. (in Ukrainian).

10.Psykholohichna entsyklopediia (Psychological encyclopedia) / Compiler O. M. Stepanov. Kyiv : Akademvydav, 2006. 424 p. (in Ukrainian).

11.Psihologo-pedagogicheskiy slovar (Psychological and pedagogical vocabulary) / Compiler E. S. Rapatsevich. Minsk : Sovremennoe slovo, 2006. 928 p. (in Russian).

12.Yatsenko T. S. Psykholohichni osnovy hrupovoi psykhokorektsii : navch. posib. (Psychological basis of group psychocorrection : Tutorial). Kyiv : Lybid, 1996. 264 p. (in Ukrainian).

13.Henson K. T. Methods and strategies for teaching in secondary and middle schools. N. Y . : Longman, 1988. X. 405 p. (in English).

Стаття надійшла до редакції 25.12.2018

I. Матійків

\section{Формування готовності психолога до майбутньої професійної діяльності}

Стаття присвячена проблемі формування психологічної готовності психологів до практичної діяльності у процесі навчання. Доведено, що підвищення якості професійної підготовки потребує розвитку особистісної та функціональної готовності майбутніх фахівців. У статті висвітлено зміст і структуру розробленого навчально-практичного інтерактивного курсу «Основи професійної майстерності психолога», який має на меті вдосконалення професійно важливих умінь і особистісних якостей, необхідних для успішного здійснення професійної діяльності. Методичними особливостями цього курсу є проблемність викладання, застосування активних та інтерактивних методів навчання, акцент на самостійній роботі студентів. Змістове наповнення занять запропонованого інтерактивного курсу може видозмінюватися залежно від особистості й рів- 
ня професійної підготовки викладача, складу групи, від кількості академічних годин. Обгрунтовано ключові принципи, переконання, ціннісні настанови, формування яких сприяє вдосконаленню особистості психолога. Автор робить висновок, що розвиток психологічної готовності майбутніх психологів до професійної діяльності та включення навчально-практичного інтерактивного курсу в процес професійної підготовки має важливе значення для підвищення ії якості.

Ключові слова: вища освіта, професійна майстерність, психологічна готовність, навчально-практичний курс, інтерактивні методи навчання.

I. Matiikiv

Formation of Psychologist's Readiness for Future Activities

The article is devoted to the problem of formation of psychological readiness of psychologists to practical activity while training. It is proved that improving the quality of professional training requires the development of personal and functional readiness of future specialists. The article describes the content and structure of the developed educational and practical interactive course «Basics of psychologist's professional skills», which aims at improving the professionally important skills and personal qualities necessary for the successful pursuit of professional activities. The peculiarities of teaching methods of this course are the problem-based teaching, the use of active and interactive teaching methods, the emphasis on students' independent work. The content of the lessons of the proposed interactive course may vary depending on the personality and level of teacher's training, the composition of the group, and the number of academic hours. The author substantiates key principles, beliefs, and values, the formation of which contributes to the improvement of the personality of the psychologist. The author concludes that the development of psychological readiness of future psychologists for professional activity and the inclusion of an educational and practical interactive course in the process of professional training is essential for improving its quality.

Key words: higher education, professional skills, psychological readiness, educational and practical course, interactive teaching methods.

Рецензент - доктор психологічних наук, професор 3. Я. Ковальчук 